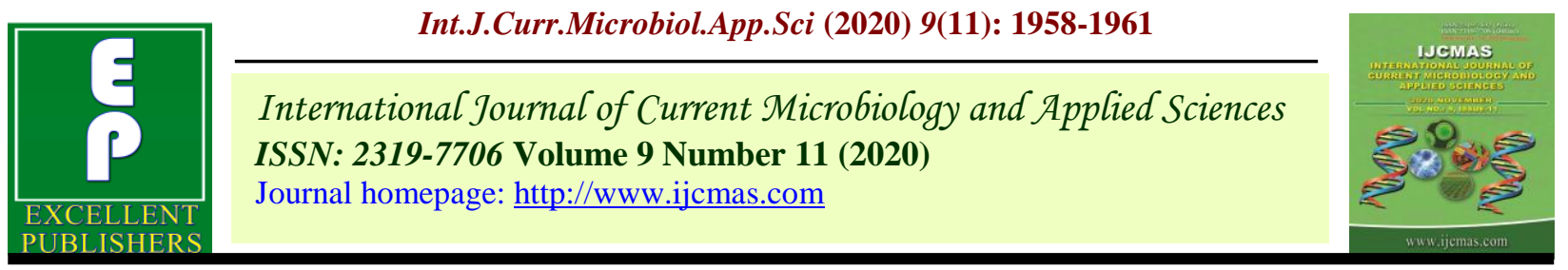

Original Research Article

https://doi.org/10.20546/ijcmas.2020.911.232

\title{
Largest Individual Ginger (Zingiber officinale Roscoe) Cluster Produced in Jute Fabrics Reinforced Soil Columns
}

\author{
A. K. Ghorai* \\ Principal Scientist, Agronomy, Crop Production Division, ICAR-Central Research Institute \\ for Jute and Allied Fibres, Barrackpore-700120, Kolkata, WB, India \\ *Corresponding author
}

K e y w o r d s
$\begin{aligned} & \text { Ginger, Jute fabrics } \\ & \text { based soil columns, } \\ & \text { Rhizome weight, } \\ & \text { Oxygen diffusion } \\ & \text { rate }\end{aligned}$
Article Info
$\begin{aligned} & \text { Accepted: } \\ & 15 \text { October } 2020 \\ & \text { Available Online: } \\ & 10 \text { November } 2020\end{aligned}$

\section{A B S T R A C T}

Ginger (Zingiber officinale Roscoe) was grown as intercrop in summer rice field followed by its sole cropping, in jute fabric based soil columns to provide better drainage and aeration to the crop at ICAR-CRIJAF research farm in 2013-14. The individual initial planting rhizome (seed) weight varied from 80-100 g each. The crop was grown with a fixed nutrition and pesticide schedule. Healthy individual ginger bushes produced as high as 139 tillers. The maximum approximate radii of ginger clusters and its depth varied from 33-45 $\mathrm{cm}$ and 10-16 cm, respectively (Fig. 1). The cluster contained large number of individual small rhizomes in compact masses all connected together. Largest ginger individual cluster, maximum up to 4.5 $\mathrm{kg}$ were developed on jute fabrics based soil columns in 9 months. Careful excise in ginger farming adopting this technology will substantially increase farmers' income. This system will also help the resource poor farmers to meet their own requirements for home scale consumption.

\section{Introduction}

Ginger (Zingiber officinale Roscoe) is a widely used herb and food flavouring agent. Its nutraceutical properties have been of interest to the food processing and pharmaceutical industries since long. It is normally sold in the form of shade dry fresh rhizomes (6-9 month old) or in preserved packets by different commercial vendors. It is normally cultivated on ridges to provide adequate drainage, as it cannot withstand waterlogging. Of late, in India, the crop loss is severe due to fungal and bacterial attack which results in rotting of rhizomes. In the northeastern hills of India, rhizome rot is incited by Pythium aphanidermatum, a highly destructive disease. Incidence of soft rot disease varied from 7.23 to $40.26 \%$ and 5.23 to $34.84 \%$ in 2012 and 2013 , respectively (Singh et al., 2018). To combat the situation, ginger rhizomes were planted on jute 
reinforced soil columns which provides adequate drainage through lateral and vertical drainage in short time, maintains proper moisture regime and improves oxygen diffusion rate in the columns over conventional ridge planting (Ghorai et al., 2013, 2014 and 2020) system.

\section{Materials and Methods}

Jute fabrics based soil columns ( $45 \mathrm{~cm}$ height and $30 \mathrm{~cm}$ radius, Fig. 2) were made in summer rice field in 2013-14 (45 days after rice transplantation, on $1^{\text {st }}$ week of April 2014) to minimise irrigation requirements of early planting ginger which is very costly at present. The hydrograph of ponding varied from $0-10 \mathrm{~cm}$ during rice growth period. The soil was sandy clay loam in texture, having 44 per cent sand, 28 per cent silt and 28 per cent clay. The soil contained 195, 51 and $124 \mathrm{~kg}$ available nitrogen, phosphorus and potassium /ha respectively. The $\mathrm{pH}$ of the soil is neutral. The ginger rhizomes (80-100 g each) were planted on soil columns, mulched with straw and watered for germination. After the rice harvest (Fig. 3 and 4), the columns were strengthened with soil and jute hessians, fertilized with $150 \mathrm{~g}, \mathrm{~N}: \mathrm{P}: \mathrm{K}:: 10: 26: 26,50 \mathrm{~g}$ urea, $500 \mathrm{~g}$ rice straw ash, $100 \mathrm{~g}$ neem cake and $100 \mathrm{~g}$ bone meal. The top radius was made upto $60 \mathrm{~cm}$ for lateral spread of rhizomes (Fig. 4). Excess water from field was drained out and the crop was treated with different fungicides (Bavistin, Blitox and Hexaconalzole) and bacteriocides (Streptocycline) to prevent rhizome rot. Some of the columns were fenced with rice straw to prevent damage of columns. To prevent termite attack systemic insecticides were sprayed. The crop was harvested at 9 month old stage (10/1/2014) and the rhizome clusters were properly washed. Fresh matured old ginger rhizomes contained $94.17 \pm 0.16 \%$ moisture when harvested at 10 to 12 months old stage (Puengphian and Sirichote, 2008).

\section{Results and Discussion}

The hessian based soil columns maintained proper moisture regime (13.0 to 23.5 per cent) in it and improved oxygen diffusion rate (280 $\mu \mathrm{gO}_{2} / \mathrm{m}^{2} / \mathrm{sec}$, ODR Meter, Eijkelkamp, The Netherlands) in the columns over conventional ridge planting (Ghorai et al., 2013) system. We did not record any rhizome rot in this system. The individual ginger tillers had 16 to 21 leaves and attained a height of $51-70 \mathrm{~cm}$. The rhizome weights were taken after thorough wash and sun drying for 5-6 hours. The detailed biometry of the crop is given in Table 1. The cluster contained many small individual rhizomes/fingers (difficult to count as the clusters are compact masses).

Table.1 Biometry of ginger crop in jute reinforced soil columns

\begin{tabular}{|c|c|c|c|c|c|c|}
\hline SI.No. & $\begin{array}{c}\text { Plant /tiller } \\
\text { height } \mathbf{( c m )}\end{array}$ & $\begin{array}{c}\text { Leaves } \\
\text { /tiller } \\
\text { (Nos.) }\end{array}$ & $\begin{array}{c}\text { Tillers/ } \\
\text { column/clump) } \\
\text { (Nos.) }\end{array}$ & $\begin{array}{c}\text { Individual } \\
\text { cluster radius } \\
\text { (approx.). cm }\end{array}$ & $\begin{array}{c}\text { Individual } \\
\text { cluster depth } \\
\text { (approx.) cm }\end{array}$ & $\begin{array}{c}\text { Individual } \\
\text { rhizome cluster } \\
\text { weight (kg) }\end{array}$ \\
\hline $\mathbf{1}$ & $55 \mathrm{~cm}$ & 15.6 & 139 & 36 & 16 & $4.50 \mathrm{Kg}$ \\
\hline $\mathbf{2 .}$ & $53 \mathrm{~cm}$ & 19.00 & 123 & 35 & 15 & $4.50 \mathrm{~kg}$ \\
\hline $\mathbf{3 .}$ & $59.2 \mathrm{~cm}$ & 17.60 & 103 & 39 & 16 & $4.50 \mathrm{~kg}$ \\
\hline $\mathbf{4 .}$ & $51.0 \mathrm{~cm}$ & 19.20 & 84 & 45 & 15 & $4.50 \mathrm{~kg}$ \\
\hline $\mathbf{5 .}$ & $70 \mathrm{~cm}$ & 20.60 & 124 & 33 & 10 & $4.50 \mathrm{Kg}$ \\
\hline $\mathbf{6 .}$ & $54.2 \mathrm{~cm}$ & 19.60 & 74 & 39 & 14 & $3.80 \mathrm{~kg}$ \\
\hline $\mathbf{7 .}$ & $59.6 \mathrm{~cm}$ & 16.20 & 89 & 45 & 16 & $3.80 \mathrm{~kg}$ \\
\hline $\mathbf{8 .}$ & $60.4 \mathrm{~cm}$ & 20.8 & 55 & 40 & 15 & $3.30 \mathrm{~kg}$ \\
\hline SD (+) & 5.98 & 1.93 & 28.56 & 4.49 & 2.07 & 0.49 \\
\hline
\end{tabular}



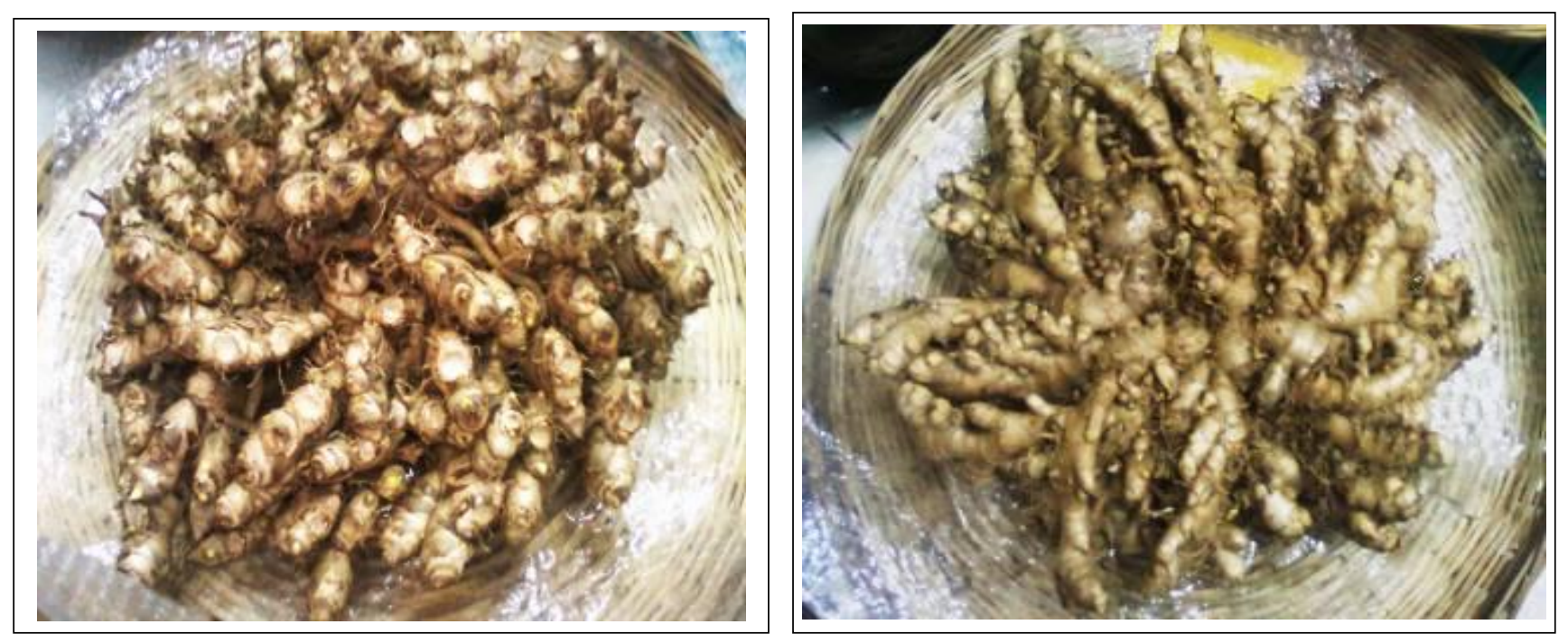

Fig.1 Surface and ventral view of a largest ginger cluster: Its sundry weight is $4.50 \mathrm{~kg}$, approximate radius is $39 \mathrm{~cm}$ and its depth/thickness is $16 \mathrm{~cm}$.
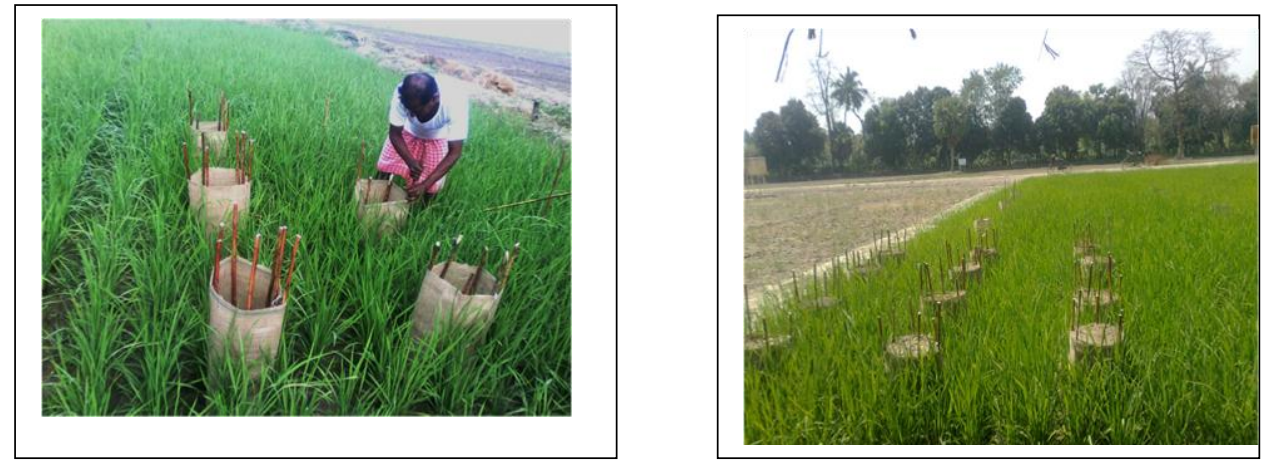

Fig 2 Jute fabrics reinforced soil columns developed in waterlogged rice field

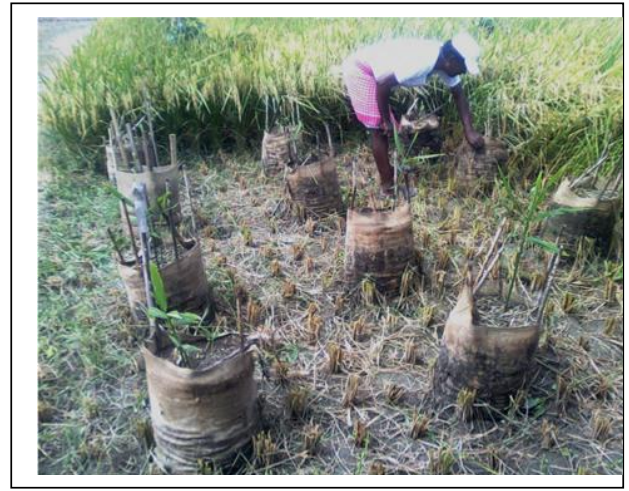

Fig.3 Soil columns with young gingers being freed from rice crop, after its harvest 

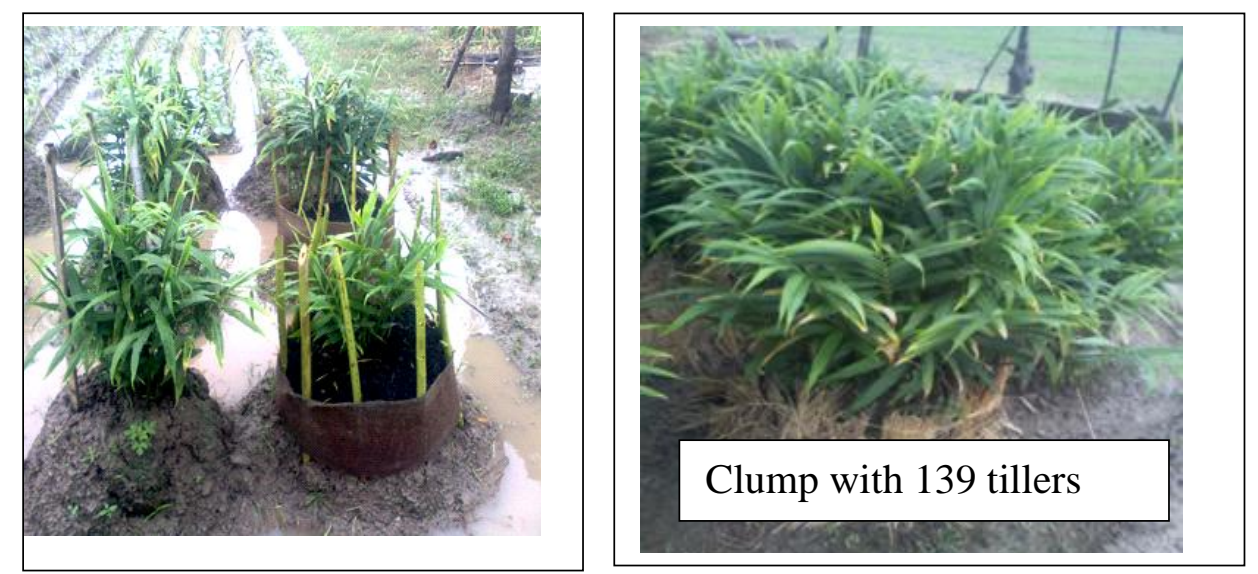

Fig.4 Earthingup, manuring and column repair of ginger after rice harvest. Few columns were tied with straw for firmness after hessian decay)

The approximate cluster radius/spread varied from (due to irregular size) varied from 33-45 $\mathrm{cm}$ and the depth of the rhizome cluster varied from 10-16 cm. The maximum weight of each rhizome was $4.5 \mathrm{~kg}$ ( $\mathrm{Sl}$. No 1 to 5). The respective columns/clumps contained 84-139 tillers (Fig. 4). We got high degree of positive correlation between tiller numbers of ginger and its rhizome weight (Eqn. 1). The cost of production was for each column was Rs.70 only and the return from each column was Rs.560.

$\mathrm{Y}=2.632+0.016 \mathrm{X}, \mathrm{r}=0.828, \mathrm{R}^{2}=0.70$

Where $\mathrm{Y}$ is the weight of rhizome clusters $(\mathrm{kg})$ and $\mathrm{X}$ is the number of tillers/column.

\section{References}

Puengphian, C. and Sirichote, A. (2008). [6]gingerol content and bioactive properties of ginger (Zingiber Officinale Roscoe) extracts from supercritical $\mathrm{CO}_{2}$ extraction. Asian J Food Ag-Ind 1(1): 29-36.
Ghorai, A. K., D. K. Kundu, Shailesh Kumar, A. Shamna and Debarati Datta. (2020). Gunny bag based soil columns for crop diversification in rice field to enhance livelihood security of land scarce farmers. Current Sci.119 (7) 1190-1195.

Ghorai, A.K., Kundu, D.K., Satpathy, S. and Ghosh, R. (2014). Crop diversification in anaerobic rice field using gunny bag reinforced soil columns. SAARC Agri News, 8(2):7-8.

Ghorai, A.K., Chowdhury, H., Kundu, D.K. and Mahapatra, B.S. (2013). Crop diversification in anaerobic rice field using woven and nonwoven jute fabrics based reinforced soil column. Presented in "ARRW Golden Jubilee International Symposium" held at Cuttak, Odisha, India from March 2-5, 2013, PP-224-225.

Singh, A. R., Dutta, S. K., Boopathi, T., Singh, S. B., Lungmuana, Saha, S., Dayal, V., P. Anita and L. S. Singh (2018). Integrated management of soft rot of ginger in Northeastern hills of India. Indian Phytopathology. 71: 83-89.

\section{How to cite this article:}

Ghorai, A. K. 2020. Largest Individual Ginger (Zingiber officinale Roscoe) Cluster Produced in Jute Fabrics Reinforced Soil Columns. Int.J.Curr.Microbiol.App.Sci. 9(11): 1958-1961. doi: https://doi.org/10.20546/ijcmas.2020.911.232 